\title{
MENINGKATKAN KEAKTIFAN BELAJAR SISWA PADA PELAJARAN IPA DENGAN MENGGUNAKAN METODE EKSPERIMEN KELAS VIII-2 SMP NEGERI 4 TEBING TINGGI
}

\author{
Mangatur Marpaung \\ Surel: mmarpaung14@gmail.com
}

\begin{abstract}
This study aims to determine the use of experimental methods in improving students' learning activeness in science lessons in class VIII-2 SMP Negeri 4 Tebing Tinggi. The subjects of the study were students of class VIII-2, amounting to 35 people. The result of research on student learning activity in the first cycle of meeting I is 71,52\% (active enough), cycle I second II that is $72,30 \%$ (active enough), in cycle II meeting I that is $82,30 \%$ (active), cycle II meeting II is $84.01 \%$ (active). The result of observation of classroom teacher about the implementation of experimental method of cycle I meeting I is $68,75 \%$ (less good), cycle I meeting II is 78,12\% (good enough), in cycle II meeting I is $87,5 \%$ (good) Cycle II meeting II is $93,75 \%$ (very good).
\end{abstract}

Keywords: Learning Activeness, Experimental Methods, IPA

\begin{abstract}
ABSTRAK
Penelitian ini bertujuan untuk mengetahui penggunaan metode eksperimen dalam meningkatkan keaktifan belajar siswa pada pelajaran IPA di kelas VIII-2 SMP Negeri 4 Tebing Tinggi. Subjek penelitian adalah siswa kelas VIII-2 yang berjumlah 35 orang. Hasil penelitian mengenai keaktifan belajar siswa pada siklus I pertemuan I yaitu $71,52 \%$ (cukup aktif), siklus I pertemua II yaitu $72,30 \%$ (cukup aktif), pada siklus II pertemuan I yaitu $82,30 \%$ (aktif), siklus II pertemuan II yaitu 84,01\% (aktif). Hasil pengamatan guru kelas tentang penerapan metode eksperimen siklus I pertemuan I yaitu $68,75 \%$ (kurang baik), siklus I pertemuan II yaitu 78,12\% (cukup baik), pada siklus II pertemuan I yaitu $87,5 \%$ (baik), siklus II pertemuan II yaitu 93,75\% (sangat baik).
\end{abstract}

Kata Kunci: Keaktifan Belajar, Metode Eksperimen, IPA

\section{PENDAHULUAN}

Pendidikan sangat penting

dalam meningkatan potensi diri setiap orang. Pendidikan merupakan usaha sadar dan terencana untuk mewujudkan suasana belajar dalam proses pembelajaran agar siswa secara aktif mengembangkan potensi dirinya. Salah satu lembaga pendidikan adalah sekolah. Sekolah merupakan lembaga pendidikan yang mempunyai tugas untuk mengembangkan segala potensi yang dimiliki oleh siswa, demikian juga dengan Sekolah menengah pertama. Pengembangan potensi yang dimiliki masing-masing siswa dengan optimal, akan meningkatkan taraf kehidupannya kelak. Untuk itu perlu

Guru SMP Negeri 4 Tebing Tinggi 
diperhatikan atau diupayakan semua komponen-komponen dalam proses belajar mengajar agar saling mendukung sehingga tercapai hasil belajar yang baik.

Belajar mengajar selaku suatu sistem instruksional mengacu kepada pengertian sebagai seperangkat komponen yang saling bergantung satu sama lain untuk mencapai tujuan. Selaku suatu sistem, belajar mengajar meliputi suatu komponen, antara lain tujuan, bahan, siswa, guru, metode, situasi, dan evaluasi. Agar tujuan itu tercapai, semua komponen yang ada harus diorganisasikan sehingga antar sesama komponen terjadi kerjasama. Karena itu, guru tidak boleh hanya memperhatikan komponen-komponen tertentu saja misalnya metode, bahan, dan evalusi saja, tetapi ia harus mempertimbangkan komponen belajar mengajar secara keseluruhan (Djamarah, 2006:9).

Guru hanyalah merangsang keaktifan belajar siswa dengan jalan menyajikan bahan pelajaran dengan menggunakan metode pembelajaran yang tepat, sedangkan yang mengolah dan mencerna adalah siswa itu sendiri. Metode yang diharapkan tepat dalam pembelajaran IPA adalah metode eksperimen. Dengan menerapkan metode eksperimen ketika proses belajar mengajar berlangsung di dalam kelas siswa belajar dan berbuat secara langsung tentang apa yang akan dipelajarinya melalui materi yang disampaikan oleh guru. Melalui pelaksanaan metode $\begin{array}{llr}\text { eksperimen } & \text { siswa } & \text { melakukan } \\ \text { berbagai } & \text { aktivitas } & \text { yang }\end{array}$ menyenangkan yang tentunya mampu merangsang munculnya keaktifan belajar. Dengan kata lain melalui penggunaan metode eksperimen siswa berpartisipasi aktif dan memperoleh pengalaman langsung, serta dapat mengembangkan kecakapannya. Uraian di atas menjelaskan bahwa penerapan metode eksperimen dapat menentukan peningkatan keaktifan belajar siswa, prediksi ini dapat dilakukan dengan melaksanakan penelitian yang berjudul: "Meningkatkan Keaktifan Belajar Siswa pada Pemlajaran IPA Dengan Menggunakan Metode Eksperimen Kelas VIII-2 SMP Negeri 4 Tebing Tinggi T.P 2016/2017.

Sesuai dengan latar belakang masalah maka dapat diidentifikasi masalah yang berkaitan dengan keaktifan belajar siswa:

1. Proses belajar mengajar dalam kelas didominasi oleh guru

2. Metode yang digunakan guru dalam pembelajaran hanya metode ceramah dan pemberian tugas

3. Siswa jarang mengajukan pendapat maupun pertanyaan terhadap penjelasan guru

4. Siswa lebih banyak menunggu sajian dari guru daripada mencari dan menemukan sendiri pengetahuan, keterampilan serta sikap yang mereka butuhkan

5. Kurangnya minat dan motivasi siswa dalam pembelajaran. 
Berdasarkan latarbelakang dan identifikasi masalah di atas dapat diketahui bahwa keaktifan belajar itu dapat dipengaruhi oleh beberapa faktor, namun dalam penelitian ini hanya dibatasi pada penggunaan metode eksperimen dalam meningkatkan keaktifan belajar siswa pada pelajaran IPA di kelas VIII-2 SMP Negeri 4 Tebing Tinggi.

Berdasarkan pembatasan masalah di atas maka rumusan masalah pada penelitian ini adalah: apakah dengan menggunakan metode eksperimen dapat meningkatkan keaktifan belajar siswa pada pelajaran IPA di kelas VIII-2 SMP Negeri 4 Tebing Tinggi.

Tujuan penelitian ini adalah: untuk meningkatkan keaktifan belajar siswa pada pelajaran IPA dengan menggunakan metode eksperimen di kelas VIII-2 SMP Negeri 4 Tebing Tinggi.

\section{METODE PENELITIAN}

Metode Eksperimen menurut Roestiyah (2008:82) memiliki kelebihan sebagai berikut:

1. Dengan eksperimen siswa terlatih menggunakan metode ilmiah dalam menghadapi segala masalah, sehingga tidak mudah percaya pada sesuatu yang belum pasti kebenarannya, dan tidak mudah pula percaya kata orang, sebelum ia membuktikan kebenarannya.

2. Mereka lebih aktif berpikir dan berbuat; hal mana itu sangat dikehendaki oleh kegiatan mengajar belajar yang modern, di mana siswa lebih banyak aktif belajar sendiri dengan bimbingan guru.

3. Siswa dalam melaksanakan proses eksperimen di samping memperoleh ilmu pengetahuan; juga menemukan pengalaman praktis serta keterampilan dalam menggunakan alat-alat percobaan.

4. Dengan eksperimen siswa membuktikan sendiri kebenaran suatu teori, sehingga mengubah sikap mereka yang tahayul, ialah peristiwa-peristiwa yang tidak masuk akal.

Dapat disimpulkan bahwa kelebihan metode eksperimen disini adalah membuat siswa lebih percaya atas kebenaran atau kesimpulan berdasarkan percobaan yang dilakukannya. Selain itu membina siswa untuk membuat terobosanterobosan baru dengan penemuan dan hasil percobaannya dan bermanfaat bagi kehidupan manusia dan untuk itu metode ini sangat penting diterapkan oleh seorang guru didalam proses belajar mengajar.

Metode Eksperimen menurut Djamarah (2006:85) memiliki beberapa kelemahan, antara lain:

1. Metode ini lebih sesuai dengan bidang-bidang sains dan teknologi;

2. Metode ini memerlukan berbagai fasilitas peralatan dan bahan yang tidak selalu mudah diperoleh dan mahal; 
3. Metode ini menuntut ketelitian, keuletan, dan ketabahan;

4. Setiap percobaan tidak selalu memberikan hasil yang diharapkan karena mungkin ada faktor-faktor tertentu yang berada diluar jangkauan kemampuan atau pengendalian.

Dapat disimpulkan bahwa kelemahan metode eksperimen disini adalah metode ini lebih sesuai diterapkan dengan bidang sains dan teknologi, memerlukan fasilitas yang kadang sulit untuk diperoleh, lebih menuntut ketelitian dan keuletan, serta tidak semua percobaan memungkinkan dapat memberikan hasil seperti yang diharapkan. Langkah-Langkah metode eksperimen, yaitu:

1. Mempersiapkan pemakaian metode eksperimen yang mencakup kegiatan-kegiatan:

a. Menetapkan kesesuaian metode eksperimen terhadap ilmu-ilmu yang hendak dicapai;

b. Menetapkan kebutuhan peralatan, bahan dan sarana lain yang dibutuhkan dalam eksperimen sekaligus memeriksa ketersediannya di sekolah;

c. Mengadakan uji eksperimen (guru mengadakan eksperimen sendiri menguji ketetapan proses dan hasilnya) sebelum menugaskan kepada siswa sehingga dapat diketahui secara pasti kemungkinan-kemungkinan yang akan terjadi;

d. Menyediakan peralatan, bahan dan sarana lain yang dibutuhkan untuk eksperimen yang dilakukan;

e. Menyediakan lembaran kerja (bila dirasa perlu).

2. Melaksanakan pemakaian metode eksperimen dengan kegiatankegiatan.

Mendiskusikan bersama seluruh siswa mengenai prosedur, peralatan dan bahan untuk eksperimen serta hal-hal yang perlu diamati dan dicatat selama eksperimen yang dilakukan oleh para siswa, dimana para siswa mengamati serta mencatat hal-hal yang dieksperimenkan dan para siswa membuat kesimpulan dan laporan tentang eksperimennya.

3. Tindak lanjut pemakaian metode eksperimen dan hasil-hasil eksperimen melalui kegiatan-kegiatan:

a. Mendiskusikan hambatan dan hasil-hasil eksperimen;

b. Membersihkan dan menyimpan peralatan, bahan, dan sarana lain;

c. Evaluasi akhir eksperimen oleh guru.

\section{METODE PENELITIAN}

Penelitian ini dilakukan di SMP Negeri 4. Jl. D.I. Panjaitan No.37 Kota Tebing Tinggi. 
Subjek dalam penelitian ini adalah siswa kelas VIII-2 SMP Negeri 4 Tebing Tinggi yang berjumlah 35 orang siswa laki-laki 16 orang dan perempuan 19 orang. Objek dari penelitian ini adalah sebagai upaya meningkatkan keaktifan belajar siswa dengan menerapkan metode eksperimen dalam pembelajaran IPA.

Penelitian ini akan

dilaksanakan pada semester I selama 3 (tiga) bulan mulai dari tahap persiapan, pelaksanaan tindakan sampai penyusunan laporan.

Jenis penelitian yang dilakukan dalam penelitian ini adalah jenis Penelitian Tindakan Kelas (classroom action research) yang mengarah kepada penggunaan metode eksperimen terhadap keaktifan belajar siswa pada pelajaran IPA di kelas VIII-2 SMP Negeri 4 Tebing Tinggi.

\section{HASIL DAN PEMBAHASAN}

Berdasarkan latar belakang masalah dan rumusan masalah pada penelitian ini, maka untuk meningkatkan keaktifan belajar siswa digunakan metode eksperimen pada pelajaran IPA pokok bahasan sifat larutan asam. Peneliti sebelumnya telah menyusun perencanaan kegiatan pembelajaran dengan menggunakan metode eksperimen untuk dilakukan pada siklus I, diantaranya:

a. Perencanaan

Kegiatan yang dilakukan guru dalam perencanaan adalah: merencanakan metode pembelajaran yang akan diterapkan dalam proses belajar mengajar; menyusun RPP dengan menggunakan metode eksperimen; mempersiapkan sumber, bahan, media dan alat bantu yang dibutuhkan dalam kegiatan eksperimen; mempersiapkan lembar observasi penerapan metode eksperimen dan lembar observasi keaktifan belajar siswa; mempersiapkan alat dan media eksperimen; serta menyiapkan alat dokumentasi.

b. Pelaksanaan

Pada tindakan siklus I, guru bertindak selaku guru pelaksana kegiatan pembelajaran di kelas dengan menerapkan metode eksperimen sedangkan teman sejawat bertindak selaku observer (pengamat) yang mengamati berlangsungnya pelaksanaan kegiatan pembelajaran yang dilakukan dan mengamati keaktifan belajar siswa selama pembelajaran berlangsung. Kegiatan yang dilaksanakan dalam tahap ini adalah melaksanakan tindakan sesuai dengan yang telah direncanakan, berupa pelaksanaan proses pembelajaran sesuai dengan rencana pelaksanaan pembelajaran dengan menerapkan metode eksperimen.

c. Observasi

Selama berlangsungnya proses pembelajaran, guru kelas VIII2 melakukan pengamatan dengan mengisi format lembar observasi yang sudah disiapkan. Hasil 
pengamatan

pelaksanaan

pembelajaran selama siklus I

pertemuan I dan Pertemuan II.

Hasil pengamatan guru kelas tentang penerapan metode eksperimen

tindakan siklus I pada pertemuan I yaitu $68,75 \%$ (kurang baik), tampak bahwa pelaksanaan pembelajaran yang dilakukan guru telah berjalan dengan baik, meskipun demikian pada beberapa aspek masih tergolong cukup baik, misalnya evaluasi akhir kegiatan eksperimen oleh guru, beberapa aspek yang lain sudah tergolong baik, misalnya mendiskusikan hambatan dan hasil eksperimen bersama seluruh siswa.

Hasil pengamatan guru kelas tentang penerapan metode eksperimen tindakan siklus I pada pertemuan II yaitu $78,12 \%$ (cukup baik), tampak bahwa pelaksanaan pembelajaran yang dilakukan guru telah berjalan dengan baik, meskipun demikian pada beberapa aspek masih tergolong cukup baik, misalnya evaluasi akhir kegiatan eksperimen oleh guru, akan tetapi pada beberapa aspek yang lain sudah tergolong baik, misalnya mendiskusikan hambatan dan hasil eksperimen bersama seluruh siswa.

Persentasi penerapan metode eksperimen selama tindakan siklus I pada pertemuan I dan pertemuan II yang dilakukan oleh guru berbeda pada setiap pertemuan. hasil pengamatan guru kelas selaku observer tentang siswa yang aktif selama tindakan siklus I pertemuan I, terdapat 4 orang siswa $(11,43 \%)$ yang keaktifan belajarnya sangat aktif, 6 orang siswa $(17,14 \%)$ yang keaktifan belajarnya tergolong aktif, 8 orang siswa $(22,86 \%)$ yang keaktifan belajarnya cukup aktif, namun 17 orang siswa $(48,57 \%)$ yang keaktifan belajarnya kurang aktif. hasil pengamatan guru kelas selaku observer tentang siswa yang aktif selama tindakan siklus I pertemuan II, terdapat 5 orang siswa $(14,29 \%)$ yang keaktifan belajarnya sangat aktif, 7 orang siswa (20\%) yang keaktifan belajarnya tergolong aktif, 9 orang siswa $(25,71 \%)$ yang keaktifan belajarnya cukup aktif, namun 14 orang siswa (40\%) yang keaktifan belajarnya kurang aktif.

\section{Refleksi Siklus I}

Hasil pengamatan pada siklus I pertemuan I, terdapat 4 orang siswa $(11,43 \%)$ yang keaktifan belajarnya sangat aktif, 6 orang siswa $(17,14 \%)$ yang keaktifan belajarnya tergolong aktif, 8 orang siswa $(22,86 \%)$ yang keaktifan belajarnya cukup aktif, namun 17 orang siswa $(48,57 \%)$ yang keaktifan belajarnya kurang aktif. Sedangkan pada siklus I pertemuan II, terdapat 5 orang siswa $(14,29 \%)$ yang keaktifan belajarnya sangat aktif, 7 orang siswa (20\%) yang keaktifan belajarnya tergolong aktif, 9 orang siswa $(25,71 \%)$ yang keaktifan belajarnya cukup aktif, namun 14 orang siswa (40\%) yang keaktifan belajarnya masih kurang aktif. 
Hasil pengamatan observer tampak keaktifan belajar siswa dalam melakukan aktivitas mendengar dan menulis tergolong kategori cukup aktif dan keaktifan siswa dalam aktivitas berbahasa masih tergolong kurang. Hasil pengamatan guru Kelas VII tentang pelaksanaan kegiatan pembelajaran dengan menggunakan metode eksperimen yang dilakukan oleh guru selama tindakan siklus I pertemuan I yaitu $68,75 \%$ (kurang baik) sedangkan pelaksanaan pembelajaran yang dilakukan oleh guru selama tindakan siklus I pertemuan II yaitu $78,12 \%$ (cukup baik).

Dengan demikian, dari hasil tindakan siklus I diperoleh kesimpulan sementara bahwa pembelajaran IPA menggunakan metode eksperimen belum sepenuhnya menjadikan siswa aktif dalam pembelajaran dimana pada pertemuan I 17 orang siswa $(48,57 \%)$ dan pada pertemuan II sebanyak 14 orang siswa (40\%) yang masih memiliki keaktifan belajar tergolong kurang aktif. Karenanya diperlukan tindakan siklus II untuk lebih meningkatkan keaktifan belajar siswa dengan mengadakan kerja kelompok, pemberian tugas, dan tanya jawab menggunakan metode eksperimen, serta lebih memberikan motivasi dan kesempatan berpikir dan bertanya kepada para siswa selama kegiatan eksperimen berlangsung di dalam kelas.

\section{Refleksi Siklus II}

Hasil pengamatan pada siklus II pertemuan I, terdapat terdapat 9 orang siswa $(25,71 \%)$ yang keaktifan belajarnya sangat aktif, 15 orang siswa $(42,86 \%)$ yang keaktifan belajarnya aktif dan 4 orang siswa $(11,43 \%)$ yang keaktifan belajarnya cukup aktif, dan 7 orang siswa (20\%) yang keaktifan belajarnya masih tergolong kurang aktif. Sedangkan hasil pengamatan pada siklus II pertemuan II terdapat 10 orang siswa $(28,57 \%)$ yang keaktifan belajarnya sangat aktif, 16 orang siswa $(45,71 \%)$ yang keaktifan belajarnya aktif dan 6 orang siswa $(17,14 \%)$ yang keaktifan belajarnya cukup aktif, dan 3 orang siswa $(8,57 \%)$ yang keaktifan belajarnya tergolong kurang aktif. Dengan demikian, keaktifan belajar siswa setelah diterapkan tindakan siklus II sudah tergolong baik, telah diperoleh ketuntasan belajar secara klasikal yakni $84 \%$ siswa yang aktif.

Hasil pengamatan guru kelas tentang penerapan metode eksperimen tindakan siklus II pertemuan I yaitu $87,5 \%$ (baik), sedangakan pengamatan guru kelas pada siklus II tindakan II yaitu 93,75\% (sangat baik). Dengan demikian tampak jelas adanya peningkatan persentasi penerapan metode eksperimen pada tindakan siklus I sampai tindakan siklus II. Keaktifan belajar siswa pada tindakan siklus II jauh lebih baik, hal ini tampak bahwa keaktifan siswa dalam melakukan aktivitas melihat dan 
melakukan aktivitas emosional telah tergolong sangat baik. Keaktifan siswa dalam aktivitas berbahasa, aktivitas mendengarkan, aktivitas menulis, aktivitas menggambar, aktivitas gerak, dan aktivitas mental telah tergolong baik.

Dengan demikian, hasil tindakan silkus II diperoleh kesimpulan bahwa pembelajaran IPA dengan menggunakan metode eksperimen dapat meningkatkan keaktifan belajar siswa di kelas VIII-2 SMP Negeri 1 Tebing Tinggi T.P 2016/2017.

\section{Pembahasan}

Selama diberikan tindakan siklus I dengan menggunakan metode ceramah, tanya jawab, kerja kelompok, pemberian tugas dan penerapan metode eksperimen keaktifan belajar siswa pada siklus I pertemuan I yaitu dari 35 siswa terdapat 4 orang siswa $(11,43 \%)$ yang keaktifan belajarnya sangat aktif, 6 orang siswa $(17,14 \%)$ yang keaktifan belajarnya tergolong aktif, 8 orang siswa $(22,86 \%)$ keaktifan belajarnya cukup aktif, namun 17 orang siswa $(48,57 \%)$ yang keaktifan belajarnya kurang aktif, sedangkan pada siklus I pertemuan II terdapat 5 orang siswa $(14,29 \%)$ yang keaktifan belajarnya sangat aktif, 7 orang siswa (20\%) yang keaktifan belajarnya tergolong aktif, 9 orang siswa $(25,71 \%)$ yang keaktifan belajarnya cukup aktif, namun 14 orang siswa (40\%) yang keaktifan belajarnya kurang aktif.
Berdasarkan hasil siklus I, perlu dilakukan tindakan siklus II untuk lebih meningkatkan keaktifan belajar siswa dengan tetap menggunakan metode ceramah, tanya jawab, kerja kelompok, pemberian tugas dan penerapan metode eksperimen selama kegiatan pembelajaran berlangsung. Selama pelaksanaan kegiatan pembelajaran pada siklus II keaktifan belajar siswa meningkat lebih baik dibandingkan siklus I, hasil pengamatan pada siklus II pertemuan I yaitu dari 35 siswa terdapat 9 orang siswa $(25,71 \%)$ yang keaktifan belajarnya sangat aktif, 15 orang siswa $(42,86 \%)$ yang keaktifan belajarnya aktif dan 4 orang siswa $(11,43 \%)$ yang keaktifan belajarnya cukup aktif, dan 7 orang siswa (20\%) yang keaktifan belajarnya masih tergolong kurang aktif.

Sedangkan hasil pengamatan pada siklus II pertemuan II terdapat 10 orang siswa $(28,57 \%)$ yang keaktifan belajarnya sangat aktif, 16 orang siswa $(45,71 \%)$ yang keaktifan belajarnya aktif dan 6 orang siswa $(17,14 \%)$ yang keaktifan belajarnya cukup aktif, hanya 3 orang siswa $(8,57 \%)$ yang keaktifan belajarnya tergolong kurang aktif. Hal ini menunjukkan bahwa kegiatan pembelajaran dengan penerapan metode eksperimen serta menggunakan metode ceramah, tanya jawab, kerja kelompok, dan pemberian tugas dapat meningkatkan keaktifan belajar siswa jauh lebih baik, meskipun terdapat 3 orang 
$(8,57 \%)$ yang masih memiliki keaktifan belajar tergolong kurang aktif, yang berarti 32 orang $(91,43 \%)$ telah tergolong keaktifan belajarnya cukup aktif, aktif dan sangat aktif.

Persentasi hasil keaktifan belajar siswa berdasarkan pengamatan observer pada tindakan siklus I pertemuan I yaitu $71,52 \%$ (cukup aktif), siklus I pertemua II yaitu 72,30\% (cukup aktif), sedangkan persentasi hasil keaktifan belajar siswa pada tindakan siklus II pertemuan I yaitu $82,30 \%$ (aktif), siklus II pertemuan II yaitu $84,01 \%$ (aktif).

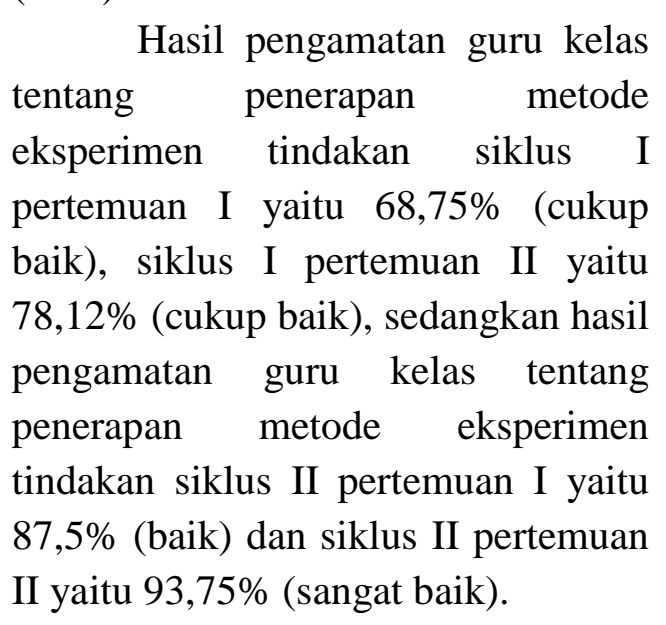

\section{SIMPULAN}

Berdasarkan hasil penelitian dan pembahasan yang telah diuraikan, diperoleh beberapa kesimpulan antara lain:

1. Pada tindakan siklus I pertemuan I, diperoleh persentase keaktifan belajar siswa sebesar $71,52 \%$ sedangkan pada pertemuan II sebesar 72,3\%.

2. Pada tindakan siklus II pertemuan I, diperoleh persentase keaktifan belajar siswa sebesar $82,3 \%$ sedangkan pada pertemuan II sebesar $84,01 \%$.

3. Terjadi peningkatan persentase keaktifan belajar siswa dari siklus I ke siklus II sebesar 11,71 dengan menggunakan metode eksperimen.

4. Terbukti bahwa dengan menggunakan metode eksperimen dapat meningkatkan keaktifan belajar siswa pada mata pelajaran IPA di kelas VIII-2 SMP Negeri 4 Tebing Tinggi T.P. 2016/2017.”

Berdasarkan hasil penelitian, pembahasan, dan kesimpulan di atas, maka disarankan beberapa hal sebagai berikut:

1. Bagi siswa khususnya siswa kelas VIII-2 di SMP Negeri 4 Tebing Tinggi diharapkan untuk lebih meningkatkan keaktifan belajarnya selama proses belajar mengajar di kelas, dan disarankan untuk tetap bersemangat dalam belajar.

2. Bagi guru diharapkan untuk dapat menciptakan kondisi belajar yang kondusif dan menyenangkan bagi siswa dan melibatkan siswa secara aktif dalam proses pembelajaran, dan disarankan untuk dapat merancang suatu metode pembelajaran yang dapat menarik perhatian siswa untuk aktif dalam belajar salah satunya dengan menggunakan metode eksperimen.

3. Bagi pihak sekolah khususnya kepala sekolah diharapkan untuk lebih memberikan perhatian terhadap keaktifan siswa dalam 
proses belajar mengajar melalui penyediaan sumber belajar maupun media pembelajaran yang tepat yang disesuaikan dengan materi dan metode sehingga guru dapat menjalankan tugas mengajarnya dengan baik.

DAFTAR RUJUKAN

Arikunto, Suharsimi. 2010. Prosedur Penelitian Suatu Pendekatan Praktik. Jakarta: Rineka Cipta.

Arikunto. Suharsimi, Suhardjono, dan Supandi, 2010. Penelitian Tindakan Kelas. Jakarta: Bumi Aksara

Djamarah, Syaiful Bahri dan Aswan Zain. 2006. Strategi Belajar Mengajar. Jakarta: Rineka Cipta.

HM, Ahmat Rohani. 2010. Pengelolaan Pengajaran Sebuah Pengantar Menuju Guru Profesional. Jakarta: Rineka Cipta.

http://visiuniversal.blogspot.com/201 4/03/pengertian-belajar-danmacam-macam.html.

https://herdy07.wordpress.com/2010/ 05/27/metode-pembelajarandiscovery-penemuan/.

Mudjiono, dan Dimyanti. 2006. Belajar dan Pembelajaran. Jakarta: Rineka Cipta.
N.K, Roestiyah. 2008. Strategi Belajar Mengajar. Jakarta: Rineka Cipta.

Slameto. 2010. Belajar dan FaktorFaktor yang Mempengaruhinya. Jakarta: Rineka Cipta.

Trianto, 2010. Model Pembelajaran Terpadu. Jakarta: Bumi Aksara. 